\title{
THE SOOTHER OF EVIL PAINS: ASCLEPIUS AND FREUD
}

\section{S Kool (School of Religion, Philosophy and Classics University of KwaZulu-Natal)}

Freud's rejection of nineteenth century psychiatry and neurology encouraged him to look for new models of diagnosis and healing. While Western medical discourse is based upon a rational approach founded upon the Hippocratic corpus, this paper argues that psychoanalysis contains many elements that can be traced to the healing cult of Asclepius. A close reading of Freud's texts reveals that he was aware of the practice of incubation at sites of healing such as Epidaurus and Pergamum and that this knowledge was incorporated into his theory and practice of dream interpretation.

\section{Introduction}

I begin to sing of Asclepius, son of Apollo and healer of sicknesses. In the Dotian plain fair Coronis, daughter of King Phlegyas, bare him, a great joy to men, a soother of cruel pangs. And so hail to you, lord: in my song I make my prayer to thee! (Homeric hymn to Asclepius 1.16).

The similarities that exist between Asclepian healing and Freudian psychotherapy form the substance of this paper. ${ }^{1}$ Over the years a number of articles have appeared which explore the relationship between modern psychotherapy and ancient practices. Often these papers have been broad and insufficient distinction is made between Freudian, Jungian, Kleinian, and Lacanian psychotherapeutic schools. ${ }^{2}$ There is very little research that interrogates the Freudian text and places Freud's understanding of these ancient practices in context. To overlook Freud's extensive knowledge of this archive is, however, a serious lacuna as it neglects his ground breaking contribution, his reception of ancient methods of healing, and the manner in which he later applied this knowledge to psychoanalysis. One requires a good grasp of the content of the ancient record, but also an understanding of how

This paper focuses on Freud's reception of the cult of Asclepius. Similarities and dissimilarities between Freud's Interpretation of dreams and Artimidorus' Oneirocritica are not addressed in this paper. Neither is the role of pagan and orphic symbolism, the Delphic oracle or Freud's interest in Egyptian hieroglyphics and dreams. These topics deserve separate consideration.

2 Both Gill 1985:307-332 and Holowchak 2002 address psychotherapy from a broad perspective. There are, however, enormous differences between the Delphic oracle's injunction to 'know yourself', Aesclepian dream interpretation, or that of music and dance therapy, just as there are differences between Freudian analysis and the Jungians' acceptance of archetypal dreams. 
Freud received and interpreted this archive. Downing's (1975:10) assertion that 'Freud's understanding of therapy is to ritual as his theory of the psyche is to myth' is succinct but it does not do justice to the variances, contradictions and transformations that we find in psychoanalysis.

The cultural impact of Hellenism on German and Austrian art, history, literature, philosophy and psychology ${ }^{3}$ is significant. My thesis has always been that it is impossible to understand the development of psychoanalysis without considering the foundational role played by German Hellenism in the creation of this new discipline. Classists often assume an affinity between psychoanalysis and classical tragedy and myth. What is often forgotten is how repeatedly Freud drew upon his classical education to construct or support his theory. Armstrong (2005) argues that psychoanalysis still participates in the uncanny after-work generated by the archive of ancient culture. He states, 'Psychoanalysis itself reflects more deeply the cultural logic, the values, the textual manoeuvres and nuances, and even the psychological interests of the ancient world' (2005:5). ${ }^{4}$ Armstrong's claims are not surprising as psychoanalysis and classical tragedy share many themes and interests. Padel (1995:239), for example, argues that Greek tragedy established the whole Western grammar of madness.

This paper does not investigate Freudian theory as a tool to analyse classical tragedy, an exercise that is often culturally anachronistic (Nussbaum 1994:44; Padel 1995:229). It is more concerned with why Freud, a neurologist, scientist and an acute observer and recorder of mental illness, rejected psychiatry to establish a new school that relied heavily upon his reception of German Hellenism. ${ }^{5}$ In his classic survey of the origin and development of dynamic psychiatry, Ellenberger (1994:896-897) concludes that Freud's departure from the concept of unified science and his institutionalisation of a new School of inquiry is modelled on the foundations of Greco-Roman antiquity.

There were a number of reasons why Freud defined psychoanalysis as an area distinct from psychiatry and neurology. First, psychiatry no longer wished to be labelled as a 'science of the soul' and argued that all nature could be explained rationally and without recourse to explanations that relied on hidden forces or energies. Freud rejected this prevailing trend in scientific thought because it minimised the importance of mental life:

3 Bell 2005 provides an analysis of classicism and its impact upon psychology.

$4 \quad$ See Butler's early and still classic thesis, The tyranny of Greece over Germany (1935), and Marchand's Down from Olympus (2003) for an analysis of philhellenism and its impact upon the intellectual culture of Austria and Germany.

5 Winter 1999 argues that classical learning, or Bildung, also provided a professional ideology that legitimated psychoanalytic professional practice and expertise. 
Anything that might indicate that mental life is in any way independent of demonstrable organic changes or that its manifestations are in any way spontaneous alarms the modern psychiatrist, as though a recognition of such things would inevitably bring back the days of the Philosophy of Nature, and of the metaphysical view of the nature of the mind (SE 4:41).

Freud's thinking, and in particular his emphasis on the unconscious and the importance of dreams, immediately aroused scientific distrust in his medical peers. Many argued that to accept Freud's theories was to break with science and align with metaphysics, mysticism, and superstition. This distrust was exacerbated by Freud's refusal to attend medical and psychiatric meetings and his insistence that his colleagues follow his example. Psychoanalysis was thus often perceived as a regressive force, a throwback to the days of the philosophy of nature. ${ }^{6}$ Along with an interest in the unconscious, the irrational, and body-mind interaction, psychoanalysis also concerned itself with the unsettling subject of human sexuality. This field of enquiry was open to enormous public censure, and contributed, especially in the early years, to the closed and elitist structure that developed around the teaching and practice of psychoanalysis. ${ }^{7}$

Secondly, psychiatry and neurology were closely aligned to biological determinism and associated theories of hereditary degeneracy. Freud contested the prevailing concepts of degeneracy in nineteenth century psychiatry and formulated a theory that had little in common with these early (and now discredited) scientific and medical discourses. ${ }^{8}$ Fin de siècle concerns about hereditary degeneration

6 'Naturphilosophie' is a nineteenth century tradition in German idealism associated with the philosophical work of Fichte, Schelling, and Hegel. It is heavily indebted to the natural philosophy of the ancient Greek Ionian philosophers. Scientists often opposed this tradition to empiricism and viewed it as speculative and metaphysical.

7 Freud divided psychoanalysis into three quite discrete areas - first, a theory, a 'scientific structure'; second, a method of inquiry, a means of exploring and ordering information; and last a mode of treatment. In his writings and lectures, Freud constantly drew attention to the inherent differences between his theory of the mind and those currently in circulation. His most original contributions to human knowledge are The interpretation of dreams (1900), a text that is concerned with the theory and interpretation of the unconscious, and Three essays on the theory of sexuality (1905) which deals with human sexuality. These two bodies of work departed substantially from the work of his colleagues and were considered highly controversial. They are still considered the bedrock of Freudian analysis and they afford us the clearest example of the development of his theory.

8 The whole thrust of institutionalising psychoanalysis can be seen as a protracted battle between psychoanalysts and psychiatrists (see Winter 1999). Freud linked the concept of degeneracy with that of psychiatry and distanced himself from its underlying racial and sexual assumptions. Psychiatrists positioned themselves within the world of science by formulating a medical model of madness and they were often perceived as 
initiated a psychiatric style of reasoning about disease, sexuality and eugenics and Freud, as a Jewish scientist practicing in Austria in the nineteenth century, was well aware of the intimate linkages that were being drawn between medicine and race (Gilman 1994:7). ${ }^{9}$ Finally, early research into hysteria by Charcot, Breuer and Freud indicated that this condition was not due to neurological disorder but to underlying psychical factors. In proposing a psychical aetiology for hysteria Freud was able to formulate his greatest discoveries; the unconscious, repression, sublimation, and transference.

One discipline that could provide an alternative to the organic evolutionism of the later nineteenth century, or to the functionalist natural history of the earlier half, was philology (Forrester 1980:167). While it is generally the case that the human sciences in the nineteenth century were dominated by biological or organic terms and that these served as guiding metaphors, it is less widely recognised (as Forrester points out) that the sciences of language, philology, exegetical sciences, comparative linguistics and historical linguistics, played a parallel and sometimes opposed role in the development of the human sciences. While analogies from biology gave rise to a social evolutionist positivism, a nonmaterialist, non-progressionist trend of social thought often gained its support from philology and its sister disciplines.

administrators of social control (Cf. Gilman 1994). Freud rejected many foundational mainstream theories including hereditary degeneration and an organic aetiology for neurosis prevalent at that time (Von Krafft-Ebing's Psychopathia sexualis [1886 / 1967] is a good example of this theorising). Unlike most psychiatrists and psychologists, Freud emphasised the importance of early childhood development, sexuality and the unconscious. This is not to say that Freud was sui generis (see for example, the footnote added by Freud in 1910, to the Three essays [1905:145] in which he acknowledges the work of sexology). Freud's rejection of what Foucault 1998:118 refers to as the 'perversion-heredity-degenerescence' hypothesis makes Freud's contribution to psychology outstanding. My paper published in Akroterion 2013:79-96, deals with this area.

9 Cocks 1992:207 claims that a systematic confrontation with psychiatry's past did not occur until the 1980s. He argues that, 'The psychiatric preoccupation with the hereditary determinants of mental illness was easily exploited by the Nazis. And apart from the authoritarian social and political views commonly held in the German professoriate often linked with this hereditarianism, psychiatrists, like physicians in general, were also heavily influenced by the eugenic thought, social Darwinism, and racism endemic to Germany during the late nineteenth and early twentieth centuries. The persistence of this way of thinking into the post war era is evident in the West German disposition of compensation cases for psychic damage caused by Nazi persecution'. 


\section{Psychoanalysis as a secret society of initiates}

You can believe me when I tell you that we do not enjoy giving an impression of being members of a secret society and of practising a mystical science. Yet we have been obliged to recognise and express as our conviction that no one has a right to join in a discussion of psychoanalysis who has not had particular experiences which can only be obtained by being analysed oneself (SE 22:69).

Freud was aware of negative publicity surrounding psychoanalysis and his lectures delivered at the University of Vienna during 1916 and 1917 were an attempt to exonerate the closed nature of psychoanalysis. ${ }^{10}$ His call to undergo psychoanalytic training rather than to scientifically evaluate it, unfortunately only reinforced the impression of a society of secret initiates. This impression was exacerbated by the formation of a protective circle of disciples around Freud. In 1913, in the face of Jung's growing disaffection, Jones proposed a secret committee to protect psychoanalysis from heretical movements within psychoanalysis.

It was in the summer of 1913 that the Committee first assembled as a whole. Freud celebrated the event by presenting us each with an antique Greek intaglio from his collection which we then got mounted on a gold ring (Jones 1964:416).

Original members of this committee included Ferenczi, Rank, Sachs, Abraham and Jones. Freud's gesture in retaining the intaglio of Jupiter for himself was highly symbolic. It emphasised his authority over his disciples and underscored the deep bond that existed between psychoanalysis and the world of classical antiquity.

In 1907 the schools of Vienna and Zurich were united and in 1908 the first meeting of the Psychoanalytical Congress took place at Salzburg. The following years saw the expansion of psychoanalysis despite internal disputes and the development of splinter groups. Psychoanalysis continued to exist independently of the University, and by 1926 there were two institutes which gave instruction in psychoanalysis. The first was founded by Max Eitingon in Berlin in 1920, followed shortly afterwards by the Vienna Psycho-Analytical Society. Psychoanalytic training was conceived as very different from medical training, experimental psychology or physiological research. Freud described these training institutes as follows:

At these Institutes the candidates themselves are taken into analysis, receive theoretical instruction by lectures on all the subjects that are important for

${ }_{10}$ Introductory lectures on psycho-analysis (SE 15 and SE 16). 
them, and enjoy the supervision of older and more experienced analysts when they are allowed to make their first trials with comparatively slight cases. A period of some two years is calculated for this training. Even after this period, of course, the candidate is only a beginner and not yet a master. What is still needed must be acquired by practice and by an exchange of ideas in the psychoanalytical societies in which young and old members meet together. Preparation for analytic activity is by no means so easy and simple. The work is hard, the responsibility great. But anyone who has passed through such a course of instruction, who has been analysed himself, who has mastered what can be taught today of the psychology of the unconscious, who is at home in the science of sexual life, who has learnt the delicate technique of psycho-analysis, the art of interpretation, of fighting resistances and of handling the transference — anyone who has accomplished all this is no longer a layman in the field of psycho-analysis. $\mathrm{He}$ is capable of undertaking the treatment of neurotic disorders, and will be able in time to achieve in that field whatever can be required from this form of therapy (SE 20:228).

This concept of training is closer to initiation or apprenticeship. Furthermore, Freud's most important domain of inquiry, human sexuality and the unconscious, made it easy for critics to discredit psychoanalysis by identifying it with the emerging trend of fin-de siècle neo-pagan thought. An attack made by Egon Freidell (1879-1938), a contemporary of Freud's, sums up some of the vehement opposition faced by psychoanalysis:

Psycho-analysis is in truth a sect, with all the signs and symbols of one rites and ceremonies, oracles and mantic, settled symbolism and dogmatism, secret doctrine and popular edition, proselytes and renegades, priests who are subjected to tests, and daughter sects which damn each other in turn. Just as the whale, though a mammal, poses as a fish, so psychoanalysis, actually a religion, poses as a science. This religion is pagan in character: it embraces nature-worship, demonology, Chthonian belief in the depths, Dionysian sex-idolization. This connection of religion with therapy, hygiene, and the interpretation of dreams existed in the ancient world also, as for example the healing sleep for the sick in the temples of Asklepios. And we have here a seer and singer working for the powers of darkness in most enticing tones, an Orpheus from the Underworld: it is a new worldwide revolt against the Gospels (quoted in Szasz 1977:71-72).

Freidell's diatribe is excessive and ill informed, but he spoke for many when he branded psychoanalysis a cult. The nineteenth century experienced an upsurge in 
neo-paganism (Noll 1996:151-161) and Freud's break with Jung can be interpreted as a desperate strategy to distance psychoanalysis from Jung's over-enthusiastic engagement in this turgid domain.

Jung was cavalier about the accusations levelled at psychoanalysis and believed that it should even more rigorously isolate itself from scientific scrutiny:

Psychoanalysis thrives only in a very tight enclave of like minds. Seclusion is like a warm rain. One should therefore barricade this territory against the ambitions of the public for a long time to come (McGuire 1988:345).

An ironic comment made by Jung to Freud in August 1910, concerning the admission of a new member, subtly acknowledges the similarities that existed between psychoanalysis and Greco-Roman initiation practices:

Winterstein has turned up, throbbing with the awe of an initiate admitted to the inner sanctum, who knows the mysteries and the hallowed rites of the Katabsion. We welcomed him with the benevolent smile of augurs (McGuire 1988:509).

Pater (1839 - 1894) saw the re-emergence of pagan sentiments as an essential hallmark of Hellenism and attributed its beginning to Winckelmann:

Still, the broad foundation, in mere human nature, of all religions as they exist for the greatest number, is a universal pagan sentiment, a paganism which existed before the Greek religion, and has lingered forward into the Christian world, ineradicable, like some persistent vegetable growth, because its seed is an element of the very soil out of which it springs (Pater 1998:128).

Freud, an exceptional example of German Hellenism, endorsed this sentiment throughout his life and he devoted a considerable amount of time to the exploration of problems associated with a rejection of this 'universal pagan sentiment' in papers such as 'Civilized' sexual morality and modern nervous illness (1908) and later in Civilization and its discontents (1930[1929]).

\section{An Orpheus from the Underworld}

Freud claimed that the interpretation of dreams was the most characteristic and peculiar feature about the young science of psychoanalysis and that with this theory, 'analysis took the step from being a psychotherapeutic procedure to being a depth-psychology' (SE 21:7). Because Freud believed that the unconscious was most readily revealed in dreams, dream interpretation became the lynch-pin of psychoanalysis. 
The epigraph at the beginning of The Interpretation of dreams (1900), 'Flectere si nequeo superos, Acheronta movebo'"1 encircles Freud's greatest work like the river of Hades. Starobinski \& Meltzer (1987:398-407) claim that this line from Virgil's epic served as the model upon which Freud was to 'construct or fortify his theory of the repressed, and the return of the repressed'. Hades thus functions as a trope for the Freudian unconscious and throughout his writing Freud relied on analogies drawn from the underworld. Like Orpheus, Hercules, Dionysus and Aeneas, Freud set out to explore this terrain, first by himself as he struggled with his own self-analysis (Selbstanalyse), and later as a guide for others. Well versed in Virgil's Aeneid, Freud was aware that this descent 'into the world below' (Virgil 7.896-901) was depicted as a place of terrifying dreams and images crowded with monsters.

In conducting analysis Freud discovered that the 'royal road of the unconscious' was also thronged with chthonian monsters:

No one who like me, conjures up the most evil of those half-tamed demons that inhabit the human breast, and seeks to wrestle with them, can expect to come through the struggle unscathed (SE 7:109).

In Greco-Roman writing, the chthonic powers were often associated with dreams (Compton 1998:303; Downing 1990:566, Holowchak, 2002). The most famous dream site in antiquity was at Epidaurus, a sanctuary dedicated to Asclepius, the god of healing. There are many myths concerning the origins and works of Asclepius. In Homer's Iliad he is portrayed as mortal who was taught the art of healing by Chiron (4.200-205) while both Pausanias ([2.26.6] 26) and Pindar $(\text { Pythian 3) })^{12}$ believed he was the son of Apollo and Coronis. At Epidaurus, Asclepius became closely associated with Apollo Maleatas and later acquired the status of a god. His influence soon spread to Athens, Pergamum, Rome, Lebene and Cos. Although Asclepius was not essentially a chthonic god, the rite of incubation and his close association with both the snake and the dog suggests that he was initially linked to the underworld. It is for this reason that each new healing site was inaugurated by the gift of a sacred snake taken from the precinct at Epidaurus.

11 'If I cannot bend the Powers Above, I will move the Infernal Regions'. This quote from Virgil's Aeneid (Book 7.425-426) appears at the beginning of Freud's opus magnus, The interpretation of dreams (1900). For an interesting analysis of Freud's use of this quotation see Starobinski \& Meltzer 1987.

12 In the Pythian ode for Hieron of Syracuse Pindar tells the story of the birth and death of Asclepius 'that craftsman of new health for weary limbs and banisher of pain, the godlike healer of all mortal sickness', Pythian 3[str.1]. 
The statue of Asclepius dominated the sanctuary at Epidaurus. Pausanias describes this statue in the following manner:

The image of Asclepius is, in size, half as big as the Olympian Zeus at Athens, and is made of ivory and gold. An inscription tells us that the artist was Thrasymedes, a Parian, son of Arignotus. The god is sitting on a seat grasping a staff; in the other hand he is holding above the head of the serpent; there is also a figure of a dog lying by his side (Pausanias [2.27.2] 27).

Even today the rod of Asclepius, a snake coiled round a staff, is used to symbolise medical practice. The Hippocratic Oath has been changed, but the original oath commenced with the following dedication, 'I swear by Apollo, the healer, Asclepius, Hygieia, and Panacea, and I take to witness all the gods, all the goddesses, to keep according to my ability and my judgment, the following Oath '. ${ }^{13}$

\section{In the temples of Asclepius}

'The sacred grove of Asclepius is surrounded on all sides by boundary marks' so begins Pausanias' description of the sanctuary at Epidaurus (Pausanias [2.27.1] 27). For over six centuries supplicants made their way to this sanctuary with its sacred groves, streams, temple and theatre in search of a cure. The most important ritual practiced here, and at all healing sanctuaries in Greco-Roman antiquity, was that of Incubation. The term incubation refers to a form of dream healing in which the supplicant, after performing a number of rituals, goes to sleep in a sacred place with the deliberate intention of receiving a healing dream. This ritual was practiced at Delos, Kos and Pergamum as well as at the shrines of heroes or chthonic daemons, and at certain chasms reputed to be entrances to the underworld. Epidaurus, however, was considered the most famous of the Asklepieia or healing temples in which incubation was practiced (Dodds 1951:110).

Fairly reliable accounts of these rituals are available from archaeological evidence, the Epidaurian records, and from the writings of Aristophanes, Herodotus, Pausanias and Aelius Aristides. At the temples of Asclepius the dream was fundamental to the healing process. Around this nucleus there were a variety of treatment methods including the use of herbal formulae, medicinal applications, ritual bathing, music, dietary changes and mental and psychical relaxation associated with the tranquility of the surroundings (Pettis 2006:114; Gill 1985:307325; Compton 1998:306). The sanctuary at Epidaurus excluded women in child-

13 Edelstein 1943 (MedicineNet.com February 8, 2015). 
birth and those who were dying (Pausanias [2.27.1] 27). ${ }^{14}$ Between the extremes of birth and death are those who suffer from sickness, anxiety, guilt, fear and uncertainty. For these sufferers the holy precinct of Asclepius offered a place of hope in ancient times.

Visitors to the temple first sacrificed to Asclepius, then purified themselves and lay down in the abaton, the incubatory building. Here they hoped to receive a healing dream from the god Asclepius. From the surviving testimonies, he appeared either directly to the sleeping patients and cured them,${ }^{15}$ or the patient's dream was interpreted by temple priests who, based on the images and symbols of the dream, diagnosed and prescribed a suitable course of treatment. ${ }^{16}$

The status of Asclepian dream as healing therapy has been heatedly debated from ancient times to the present. For philosophers such as Aristotle the idea of a god causing a dream is preposterous:

The fact that all persons, or many, suppose dreams to possess a special significance, tends to inspire us with belief in it [such divination], as founded on the testimony of experience; and indeed that divination in dreams should, as regards some subjects, be genuine, is not incredible, for it has a show of reason; from which one might form a like opinion also respecting all other dreams. Yet the fact of our seeing no probable cause to account for such divination tends to inspire us with distrust. For, in addition to its further unreasonableness, it is absurd to combine the idea that the sender of such dreams should be God with the fact that those to whom he sends them are not the best and wisest, but merely commonplace persons. If, however, we abstract from the causality of God, none of the other causes assigned appears probable (Aristotle 1952:707).

14 According to Pausanias, the Roman senator Antoninus Pius restored part of the sanctuary: 'the Epidaurians about the sanctuary were in great distress, because their women had no shelter in which to be delivered and the sick breathed their last in the open, he provided a dwelling, so that these grievances also were redressed. Here at last was a place in which without sin a human being could die and a woman be delivered' (Paus.[ 2.26.6-7] 27).

15 In this context, the word Oneiros, according to Dodds (1951:104) means a dream figure not a dream experience, as it was considered entirely independent of the dreamer. It is for this reason that the Homeric Greeks spoke about 'seeing' a dream, rather than of 'having' a dream.

16 Downing 1990:551-575 claims that in the Hellenistic period Epidaurus and the Asclepian shrine at Kos were run by physicians, with the dreams providing prescriptions for treatment rather than effecting the cure directly. Hollowchak 2002:160 supports this claim and argues that by the second century AD the healers were predominantly consulting physicians, not cheiric practitioners. 
Despite the intellectual elitism in Aristotle's statement, most rational people would agree with him. Freud certainly discounted the divine nature of dreams, ${ }^{17}$ but his experience in treating mental disorders such as neurosis and hysteria convinced him of the therapeutic importance of dream interpretation.

It may safely be anticipated that systematic modern mental treatment, which is a quite recent revival of ancient therapeutic methods, will provide physicians with far more powerful weapons for the fight against illness (Freud SE 7:302).

Freud's position ran contrary to dominant medical discourse. Western medicine always represented itself as a rational science founded upon Logos and viewed Hippocrates, not Asclepius, as its legitimate precursor. An anonymous article published in 1922 in the British Medical Journal provides a good illustration of this position. Here the author argues that Hippocrates is as far removed from the practice of the priesthood of Asclepius, 'as are the researches of a great modern physiological laboratory from the practice of Lourdes'. The paper closes with the following comment:

The main course of ancient scientific medicine was manifestly separate from that of the worship of the god of healing. It is the spirit of Hippocrates and Aristotle, and not that of Aesculapius and Chiron the Centaur, that rules the medicine of our time (British Medical Journal 1922:883).

Freud did not accept this opposition between Asclepius and Hippocrates, between therapeutic healing and scientific medicine,

Apart from the diagnostic value ascribed to dreams (e.g. in the works of Hippocrates), their therapeutic importance in antiquity must also be borne in mind. In Greece there were dream oracles, which were regularly visited by patients in search of recovery. A sick man would enter the temple of Apollo or Aesculapius, would perform various ceremonies there, would be purified by lustration, massage and incense, and then, in a state of exaltation, would be stretched on the skin of a ram that had been sacrificed. He would then fall asleep and would dream of the remedies for his illness. These would be

17 In The occult significance of dreams (1943) this view is uncompromising. 'I am therefore of opinion that after one has taken into account the untrustworthiness, credulity and convincingness of most of these reports, together with the possibility of falsifications of memory facilitated by emotional causes and the inevitability of a few lucky shots, it may be anticipated that the spectre of veridical prophetic dreams will disappear into nothing' (SE 19:135). 
revealed to him either in their natural form or in symbols and pictures which would afterwards be interpreted by the priests (SE 4:34). ${ }^{18}$

In The interpretation of dreams (1900) Freud discusses many of the ancient seminal works on dreams. Artemidorus's Oneirocritica is perhaps the most famous, but he also consulted Aristotle's De somniis and De divinatione per somnum, Plato's Republic, Hippocrates' Ancient medicine and Regimen, Cicero's De divinatione, and Lucretius' De rerum natura. His secondary reading was substantial and included Rohde's Psyche (1890-1894), Gomperz's Traumdeutung und Zauberei (1866), Bouché-Leclercq's (1879-1872) Histoire de la divination dans l'antiquité, and the, still brilliant, Traum und Traumdeutung in Altertum (1868) by Büchsenschütz.

\section{The interpretation of dreams and therapeutic healing}

The author of the Interpretation of dreams has ventured, in the face of the reproaches of strict science, to become a partisan of antiquity and superstition (SE 9:7).

Hippocrates' On regimen and Aristotle's On dreams and On divination in sleep, are texts that both attempt to offer a rational explanation of dreams by relating them to the physiological state of the dreamer. Freud accepted that some dreams may arise from internal organic somatic stimuli but based upon his own empirical observations, 'in the course of my psycho-analysis of neurotics I must already have analysed over a thousand dreams' (SE 4:104), he argued that dreams were not merely biological epiphenomena, but were meaningful and therefore open to interpretation.

'Psyche,' Freud wrote, 'is a Greek word which may be translated mind. Thus psychical treatment means mental treatment' (SE 7:283). He argued that it was impossible to reduce the psyche to the conscious domain, a thesis that led to his greatest discovery, the unconscious. In brief, the Freudian unconscious is a topographical concept which contains all the content unavailable to the conscious mind. Freud argued that all experiences that are incompatible with the ethical and aesthetic standards of a subject's personality are likely to be repressed and forced into the unconscious. These repressed desires often manifest themselves in pathological symptoms that are found in psychoneurosis. In Freudian therapy the patient is encouraged to explore his or her dreams and to freely associate by taking the elements in the manifest dream as a point of departure. By restoring the

18 Pausanias describes the sacrifice of a sheep, stating that the dreamer would then sleep upon the fleece, but Freud's description of sleeping on a ram's fleece is probably derived from Rohde's Psyche (1890-1894). 
connections in the dream, the latent, or repressed material in the dream is made conscious and the underlying meaning of the dream is exposed. In analysing and interpreting the dream both the patient and the analyst are able to gain knowledge into the underlying cause of the illness, thereby opening the way for diagnosis and healing to take place.

Freud wrote, "let us embrace the prejudice of the ancients and of the people and let us follow in the footsteps of the dream-interpreters of antiquity' (SE 15:87) ${ }^{19} \mathrm{He}$, nevertheless, identified a number of essential differences between his technique and ancient methods of dream interpretation. First, psychoanalysis imposes the task of interpretation upon the dreamer, rather than relying exclusively upon the skill of the dream diviner. Secondly, Freud discarded the view that dreams could foretell the future, a position that ran contrary to the ancient methods of interpretation which foregrounded the predictive value of dreams. Finally Freud rejected miraculous organic cures, recorded, for example, on the votive inscriptions or iamata.

He never, however, doubted that healing occurred at Epidaurus:

It would be convenient, but quite wrong, simply to refuse all credence to these miraculous cures and to seek to explain the accounts of them as a combination of pious fraud and inaccurate observation. Though an explanation of this kind may often be justified, it is not enough to enable us to dismiss entirely the fact of miraculous cures. They do really occur and have occurred at every period of history (...). There is no need however, to bring forward anything other than mental forces in order to explain miraculous cures (SE 7:290).

Headaches, disorders of the stomach, paralysis, blindness, vomiting, and mental disorientation were frequent symptoms recorded at Epidaurus. For Freud these symptoms immediately suggested a psychosomatic aetiology rather than organic disease. Based upon his experience in treating neurosis he also recognised that the surprising cures attributed to the power of Asclepius closely resembled the remarkable recovery made by hysterical patients under the guidance of the hypnotist or the psychoanalyst.

One of the clearest statements of Freud's approach to Seelenbehandlung, or psychical treatment, was written in 1905: ${ }^{20}$

19 While followers of different schools of philosophy professed divergent beliefs regarding the cause and diagnostic value of dreams, Retief \& Cilliers 2005:841-884 conclude that there was little animosity between the Asclepian cult and rational physicians and that therapeutic techniques used by the Asclepian priests were not really very dissimilar to the Hippocratic physician's therapeutic potential.

20 Psychical (or mental) treatment (SE 7:283-302). 
Physicians have practised mental treatment from the beginning of time, and in early days to a far greater extent even than today. If by mental treatment we mean an endeavour to produce such mental states and conditions in the patient as will be the most propitious for his recovery, this kind of medical treatment is historically the oldest. Psychical treatment was almost the only sort at the disposal of the peoples of antiquity, and they invariably reinforced the effects of therapeutic potions and other therapeutic measures by intensive mental treatment. Such familiar procedures as the use of magical formulas and purificatory baths, or the elicitation of oracular dreams by sleeping in the temple precincts, can only have had a curative effect by psychical means. The physician's personality acquired a reputation derived directly from divine power, since in its beginnings the art of healing lay in the hands of priests. So that then as now the physician's personality was one of the chief instrument for bringing the patient into a state of mind favourable for his recovery (SE 7:292).

In this passage, Freud collapses centuries of ritual healing into a creative psychotherapeutic structure. Records indicate that, especially in Late Antiquity, patients could spend up to six months within the temple complex and excavations have revealed permanent hostel-like structures. During the Roman era, the purification baths adjacent to the temple were extended and cold and hot pools were constructed. The sanctuary thus grew to resemble the exclusive clinics and sanatoriums of the nineteenth century in which hydrotherapy, relaxation, music and hypnosis played an important part.

No stranger to the curative value of balneotherapy, Freud visited Karlsbad on a number of occasions. In July 1911 he informed Jung that he was at the spa resort in the hope of recovering his health (McGuire 1988:433). A few days later he, somewhat sardonically, wrote:

My cure in Karlsbad is not an unmingled pleasure. I have decided to endow a votive tablet if only I get rid of all the ailments I have acquired here. However it looks as if I were going to come off with some benefit (McGuire 1988:436).

At Epidaurus votive tablets recording the cures that had taken place were prominently displayed in the sanctuary and Freud's reference to this practice indicates how closely he associated therapy and cure with Epidaurus.

Gill (1985:308), accepts that the nearest equivalents to modern psychotherapy are to be found at the borders of certain ancient areas, between religion and medicine, on the one hand, and medicine and philosophy on the other. Drawing on Aelius Aristides' Sacred tales and Apuleius' Metamorphoses, he 
claims that Asclepius' temple provided a psychotherapeutic context, but he argues that 'its methods are unlike any modern psychotherapy' in that they failed to provide a framework that allowed patients to explore their individuality and 'find a very personal treatment for a very personal disease' (Gill 1985:312). Despite Gill's excellent arguments in support of this thesis, it is difficult to ignore Freud's explicit statement that psychoanalytic treatment is a revival of ancient healing practices, and that, 'then as now the physician's personality was one of the chief instruments for bringing the patient into a state of mind favourable for his recovery' (SE 7:292). In making this statement, Freud suggests the close affinity between Asclepian medicine and psychoanalysis.

It has been argued that the desire for a more personal god arose in the fifth century $\mathrm{BC}$, and that this desire transformed Asclepius into a responsive therapeutic figure of healing, authority and power (Martin 1987:70-72). An important reason why Asclepius' cult continued to flourish in later centuries is because it catered to the rising individualism of the fourth and ensuing centuries. Dillon (1994:255) claims that Asclepius' appeal can be directly attributed to the personal nature of his cult. He appeared in dreams, spoke to specific individuals, and even joked with them. The close bond between healer and patient is most famously expressed by Aristides in the Sacred tales, but, from its inception the cult's greatest emphasis was placed upon the god's appearance in the dream.

Freud believed that the special relationship between the physician and the patient formed an essential element in any healing process. He assured medical practitioners that psychotherapy 'is in no way a modern method of treatment', but on the contrary, 'it is the most ancient form of therapy in medicine' (SE 7:258). In a lecture he cautioned his audience, 'All physicians, therefore, yourselves included, are continually practising psycho-therapy, even when you have no intention of doing so and are not aware of it; it is a disadvantage, however, to leave the mental factor in your treatment so completely in the patient's hands' (SE 7:258). This relationship between patient and psychoanalyst was seen by Freud as a pact in which the analyst's knowledge gives the patient's ego back its mastery over the lost provinces of his mental life. It is this pact, Freud asserts, that 'constitutes the analytic situation' (SE 23:175).

The 'magic of words' is an essential part of the physician's power in conducting psychoanalysis. In his ground-breaking work, The Greeks and the irrational, Dodds (1951) also accepts an individual relationship between ancient healers and their patients.

In the morning, those who had been favoured with the god's nocturnal visitation told their experiences. And here we must make generous allowance for what Freud called 'secondary elaboration', whose effect is, in 
Freud's words, 'that the dream loses the appearance of absurdity and incoherence, and approaches the pattern of an intelligible experience (Dodds 1951:115).

Freud wrote that expectation, 'coloured by hope and faith', is an effective force 'in all our attempts at treatment and cure' (SE 7:289). Probably he had Epidaurus in mind. Supplicants to Epidaurus believed that they were in the presence of a healing god, and this expectation was further encouraged by rituals and votive offerings attesting to his miraculous intervention. Asclepius, like the therapist, thus becomes a catalyst in the healing process.

Compton (1998:305) argues that the characteristic suggestibility of psychosomatic illness was reinforced by the ceremonial nature of the sanctuary experience.

The ceremonial nature of the sanctuary experience made a deep impression on the minds of the sick. (Imagine the temple priest leading suppliants through the Asklepieion reciting to them all of the miracles performed by the healing god). Undoubtedly, patients were profoundly influenced by the Asklepieion priests who had told them that they would have dreams with cures or curative instructions (Compton 1998:305-306).

Freud realised that dreams may be influenced by suggestion and that this compliance towards the analyst could play an important role in the analysis (SE 15:114). He therefore constructed a powerful domain, a healing sanctum, to replace the temple precinct. His remarkable collection of antiquities provided a transitional space between the modern and the ancient world, and Gay for example, comments that both, 'analysands and colleagues visiting his apartment stood in awe of the brigade of statuettes he had gathered across the years' (Gay 1998:140). In a letter to Fliess, Freud refers to the silence of his consulting rooms, and adds, 'This is a good place to dream' (Masson 1995:354). Hacking (2001:258) makes the astute observation that in ancient times patients journeyed to Epidaurus to have a healing dream, while in the twentieth century, the holy site for dreams becomes the couch. Essential in each case is the dream experience and its interpretation. Exploring the relationship between incubation and psychotherapy, Downing (1990: 556) mentions an interesting etymological detail; at Epidaurus suppliants in the abaton, or sleeping room, lay on a Kline, or couch, covered in animal skins and it is from this word that modern clinics derive their name.

In all his writings Freud obstinately and controversially asserted that dreams revealed the underlying sexual origin of neurosis. From Epidaurus to Lourdes, from Herculaneum to St. Cosmo's church at Isernia, sexuality and fertility were a fundamental concern of human life. Asclepius was often associated with eros, and 
barren women journeyed to the temple to be made fertile. Pausanias writes that the Asklepieion at Epidaurus included a picture of Eros in the sleeping chamber across from the temple. Deeply interested in pagan symbolism and its survival in modern life, Freud was aware of how frequently facsimiles of the sexual organs, as votive offerings, were discovered in ancient and Christian places of healing.

Asclepius and Freud embodied a very special form of healing, a form of healing in which the body, desire, and dream intermesh. Morris (2007:419-441) claims that the triumph of Western medicine and its concurrent gains in the rational knowledge of disease have entailed a suppression of eros. In the protracted historical struggle between Asclepius and Hippocrates, Asclepius was not so much defeated by the followers of Hippocrates as erased. An erasure, Morris argues, that corresponds, 'to a disciplinary loss of memory regarding any relations between medicine and eros in favour of a dominant counter-narrative that constructs a Hippocratic forward march of scientific reason and progress' (Morris 2007:419).

Freud understood that the erotic current is fundamental to human nature. He thus expanded the understanding of sexuality:

Moreover, what psycho-analysis called sexuality was by no means identical with the impulsion towards a union of the two sexes or towards producing a pleasurable sensation in the genitals; it had far more resemblance to the allinclusive and all-preserving Eros of Plato's Symposium (SE 19:218).

Every aspect of psychoanalysis acknowledges the importance of eros. This includes the role of the healing physician. Freud argued that in the hands of an experienced physician eros becomes one of the most powerful therapeutic instruments in the dynamics of the process of cure. The Freudian concept of transference is complex, but in its broadest sense it refers to the intense relationship which develops between the patient and the psychoanalyst in the course of treatment. Freud incorporated the emergence of erotic transference into the analytic situation, regarding it as one of the most important therapeutic tools for it allows the physician to force the deeply hidden erotic life of the patient into consciousness and therefore under control (SE 12:161).

\section{Conclusion}

The testimonies at Epidaurus are an indication of the ancient trust in the therapeutic effects of dreams. Freud followed in the footsteps of this ancient practice and his exploration of the relationship between dream, truth, knowledge and sexuality still dominate our thinking. Although Freud drew heavily upon his extensive classical knowledge in both supporting and formulating psychoanalysis, the use of this material is neither imitation nor replication. It is more helpful to see 
Freud as a catalyst that transforms both art and science, the past and the present into a new compound. Freud was a neurologist, not a classical scholar, but his Gymnasium education, his milieu, and his lifelong engagement with antiquity provided him with an impressive knowledge of Greco-Roman antiquity. It would be naïve and simplistic to claim that Freud imposed meaning on human development drawn from antiquity. Rather, there is a dialectical relationship between Freud and antiquity. It is this relationship which provided the stimulus for a unique form of healing in which the ancient art of dream interpretation and the healing art of Asclepius combine with neurological science to achieve something extraordinary in the history of medicine.

\section{BIBLIOGRAPHY}

Anonymous 1922. Aesculapius. The British Medical Journal 2. 3227:882-883.

Armstrong, R H 2005. A compulsion for antiquity. New York: Cornell University Press.

Aristotle 1952. Trans. J I Beare. Aristotle: On prophesying by dreams (De divinatione per somnum). Chicago: Encyclopaedia Britannica, Inc.

Bell, M 2005. The German tradition of psychology in literature and thought 17001840. Cambridge: Cambridge University Press.

Butler, E M 1935 / 1958. The tyranny of Greece over Germany. Boston: Beacon Press.

Cocks, G 1992. Repressing, remembering, working through: German psychiatry, psychotherapy, psychoanalysis, and the 'Missed Resistance' in the Third Reich. The Journal of Modern History 64:S204-S216. Supplement: Resistance against the Third Reich.

Compton, M T 1998. The union of religion and health in ancient Asklepieia. Journal of Religion and Health 37. 4:301-312.

Dillon, M P J 1994. The didactic nature of the Epidaurian iamata. Zeitschrift für Papyrologie und Epigraphik 101:239-260.

Dodds, E R 1951. The Greeks and the irrational. Berkeley \& Los Angeles: University of California Press.

Downing, C 1975. Sigmund Freud and the Greek mythological tradition. Journal of the American Academy of Religion 43.1 (Mar.):3-14.

Downing, C 1990. Only the wounded healer heals. The testimony of Greek mythology. Soundings: An Interdisciplinary Journal 73.4:551-57566.

Edelstein, L 1943. From the Hippocratic oath: Text, translation, and interpretation. Baltimore: Johns Hopkins Press, MedicineNet.com February 8, 2015.

Ellenberger, H F 1994. The discovery of the unconscious: The history and evolution of dynamic psychiatry. London: Fontana Press. 
Foucault, M 1978. The will to knowledge. London: Penguin books.

Forrester, J 1980. Language and the origins of psychoanalysis. Oxford: Macmillan Press.

Freud, S 1900. The interpretation of dreams. SE 4.

Freud, S 1900. The interpretation of dreams. SE 5:339-627.

Freud, S [1901] 1905. Fragment of an analysis of a case of hysteria. SE 7:7-134.

Freud, S 1905. Three essays on the theory of sexuality. SE 7:125-245.

Freud, S 1905. Psychical (or mental) treatment. SE 7:283-302.

Freud, S 1907[1906]. Delusions and dreams in Jensen's Gradiva. SE 9:7-95.

Freud, S 1916-1917[1915-17]. Introductory lectures on psychoanalysis. SE 16:243-448.

Freud, S 1920. Beyond the pleasure principle. SE 18:7-64.

Freud, S 1925. Some additional notes on dream-interpretation as a whole. SE 19:127-145.

Freud, S 1925 [1924]. The resistances to psycho-analysis. SE 19: 213-224.

Freud, S 1926. The question of lay analysis. SE 20:183-258.

Freud, S 1930. Civilization and its discontents. SE 21:64-145.

Freud, S 1933. New introductory lectures on psycho-analysis. SE 22:5-182.

Freud, S 1940 [1938] An outline of psycho-analysis. SE 23:144-207.

Freud, S 1943. The occult significance of dreams. SE 19:135-138.

Gay, P 1998. Pleasure wars. Great Britain: Harper Collins.

Gill, C 1985. Ancient psychotherapy. Journal of the History of Ideas 46.3:307-325.

Gilman, S L 1994. The case of Sigmund Freud. Medicine and identity at the fin de siècle. Baltimore \& London: The Johns Hopkins University Press.

Hacking, I 2001. Dreams in place. The Journal of Aesthetics and Art Criticism 59.3:245-260.

Holowchak, A M 2002. Ancient science and dreams. Oneirology in Greco-Roman antiquity. New York: University press of America.

Homer 1966. The Iliad. Trans. E V Rieu. Harmondsworth: Penguin Books Ltd.

Jones, E 1964. The life and work of Sigmund Freud. New York: Basic Books, Inc.

Kool, S 2013. A matrix of interests: Freud, the sexologists, and the legacy of Greece. Akroterion 58:79-96.

Laplanche, J \& Pontalis, J B 1973. The language of psycho-analysis. New York, London: W W Norton \& Company.

Von Krafft-Ebing, R 1886 / 1967. Psychopathia sexualis. London: Mayflower-Dell Paperback.

Marchand S L 2003. Down from Olympus. Archaeology and philhellenism in Germany, 1750-1970. Princeton: Princeton University Press.

Martin, L H 1987. Aelius Aristides and the technology of oracular dreams. Historical Reflections / Réflexions Historiques 14.1:65-72. 
Masson, J M Ed. 1995. The complete letters of Sigmund Freud to Wilhelm Fliess 1887-1904. Cambridge Massachusetts \& London: The Belknap Press of Harvard University Press.

McGuire, W (Ed.) 1988. The Freud / Jung letters. Cambridge MA: Harvard University Press.

Miller, P C 1998. Dreams in Late Antiquity. Princeton New Jersey: Princeton University Press.

Morris, D B 2007. Un-forgetting Asclepius: An erotics of illness. New Literary History 38.3: Biocultures 419-441.

Noll, R 1996. The Jung cult. London: Fontana Press.

Nussbaum M C 1994. The Oedipus Rex and the ancient unconscious. In Rudnytsky, P L \& Spitz, E H (eds.), Freud and forbidden knowledge. New York \& London: New York University Press.

Padel, R 1995. Whom the gods destroy: Elements of Greek and tragic madness. Princeton, New Jersey: Princeton University Press.

Pater, W 1998. The Renaissance. Oxford: Oxford University Press.

Pausanias 1918. Description of Greece. Trans. W H S Jones \& H A Omerod. Loeb Classical Library Volumes. Cambridge, MA, Harvard University Press; London, William Heinemann Ltd.

Pettis, J B 2006. Earth, dream, and healing: The integration of materia and psyche in the Ancient World. Journal of Religion and Health 45.1:113-129.

Pindar, 1972. The odes of Pindar. Trans. G S Conway. London: J M Dent \& Sons Ltd.

Retief, F P \& Cilliers L 2005. Medical dreams in Graeco-Roman times. SAMJ 95. 11:842-844.

Rohde, E 1925. Psyche. The cult of souls and belief of immortality among the Greeks. London: Kegan Paul, Trench, Trubner \& Co Ltd.

Starobinski, J \& Meltzer, F 1987. Acheronta movebo. Critical Inquiry 13.2:394407.

Szasz, T 1977. Karl Kraus and the soul-doctors. London: Routledge \& Kegan Paul.

Virgil, The Aeneid. Trans. 1983 R Fitzgerald. Harmondsworth, England: Penguin Books.

Winter, S 1999. Freud and the institution of psychoanalytic knowledge. Stanford: Stanford University Press. 